\title{
A Comparative Parametric Evaluation of Informal and Formal Housing: Maltepe/Istanbul Case Study
}

\author{
Aylin Akçabozan, Ylldız Technical University \\ Yüksel Demir, Istanbul Technical University
}

\begin{abstract}
The intention of this paper is to provide a comparative parametric approach that to analyze informal housing patterns and to develop alternative housing paradigms by designing new formal housing patterns in Istanbul. This paper focuses on parameters which are effective in the formation of "informal housing settlements" considering the formal housing production alternatives. Observation, actual sources and parametric evaluation was used. This study aims to make comparison between organic informal housing structure and formal housing structure in Maltepe/ Istanbul housing settlement and analyse their physical and spatial patterns by using parametric evaluation approach.
\end{abstract}

Keywords - Architecture, mass production, parameter estimation, urban areas.

Currently one of the most controversial topics in Istanbul is the mass housing projects in informal housing settlements. According to the government housing policy, the most part of Istanbul should be demolished and reconstructed with legal structures like mass housing blocks. Cultural, spatial and formal patterns in informal housing settlements are important for analyzing and designing processes.

In this article the Maltepe / Istanbul case was chosen to discuss informal and formal housing patterns. This study aims to make the comparison between the organic informal housing structure and formal housing structure in Maltepe/ Istanbul housing settlement and to analyze their physical and spatial patterns by using parametric evaluation approach. The intention is to provide a comparative parametric approach that helps to analyse informal housing patterns and to develop alternative housing paradigms by designing new formal housing patterns.

Within the framework of informal and formal housing discussion some hypotheses were stated:

H1: Analysis and evaluation of parameters, which are effective in formation of informal housing settlements, could be used as an input for new formal housing settlement design.

H2: Analysis and evaluation of parameters could lead to systemic/parametric design approach. Systematic design approach allows us to achieve rational results.

H3: By systematic design approach and different housing production processes healthy and rational housing environments could be generated instead of standard approaches like mass housing.

An introduction is provided to define informal and formal housing and its parameters which are effective in the formation of the housing within the concept of urban and architectural perspective. The concepts and theories were derived primarily from mass housing models with a brief explanation of relevant housing research theories from a spatial and physical perspective. Observation, actual sources and discourse analysis were used to reconstruct its space-time contexts.

\section{INFORMAL AND FORMAL HOUSING}

Frameworks were designed to analyse the comprehension of informal settlements which have recently become actual with urban transformation and renewal projects. Such frameworks search how to integrate an understanding of built form during the process and to use some parameters to accommodate the social and structural contexts within such developing environments.

The issue raised by these frameworks about how the transformation of informal settlements should be altered are discussed with illustrations and diagrams. Informal housing is defined as a transition space on the intersection from urban to rural; actually it is a type of speculative urban housing that allows maximum earning with minimum investment [1,92]. Many descriptions of squatter settlements have the potential to include informality and randomness.

Generally, informal settlement is a major problematic area where low income groups who migrate from rural to urban regions live in developing countries. Although these areas are new, there is no legal control to allow self-development. Davis classifies the informal and formal housing typology: formal housing in metropolitan centres is cheap rentals, rental houses built for the poor, public housing, mass housing and dormitories; informal housing is licensed or unlicensed squatters [2, 47].

The most prominent feature of informal housing is the constant change reflecting its insecurity regarding the shelter. According to Kiray, informal house is in a constant change that can be stopped or restarted at any time in parallel with the process of housing construction and socio-economic and socio-cultural changes [3].

Informal housing production is usually carried out with easily accessible materials. The building is an unfinished structure which is produced with converted materials and is open to new additions. Informal housing is made to the first housing needs and it is fast and instant production that may change over time.

The most important discriminant feature between the informal and formal is "incompleteness". The formal housing process can not be changed during or after the application because of the pre-designed plan, structure and material. Another key feature is design by constructing to the contrary of the formal housing production. The potential of design by constructing provides flexibility in design. By considering the changing needs the informal housing is open to adaptation. Organizations which ignore the potential of informal housing and plan the evacuation of informal settlements suggest cheap apartments for people. People who live in informal settlements are aware that living in formal apartments will reduce the production and manufacturing facilities $[4,168]$. 
TABLE I

Parametric Evaluation and System Design Approach

\begin{tabular}{|c|c|c|}
\hline Parameter analysis & Parametric evaluation & System Design \\
\hline $\begin{array}{l}\text { Determination of settlement, architectural design, } \\
\text { infrastructure parameters. }\end{array}$ & $\begin{array}{l}\text { Definition of parameters which are effective in the formation } \\
\text { of informal \& formal housing settlements. }\end{array}$ & $\begin{array}{l}\text { Parametric evaluation. } \\
\text { Optimization of the results. }\end{array}$ \\
\hline Socio-cultural parameters. & Appropriate values of design parameters are modelled. & $\begin{array}{l}\text { System design using computer-aided } \\
\text { design systems. }\end{array}$ \\
\hline Economical parameters & Production of alternative approach to formal housing. & Design Proposal. \\
\hline Sustainable environment parameters. & Alternative model evaluation. & Construction of new formal housing. \\
\hline
\end{tabular}

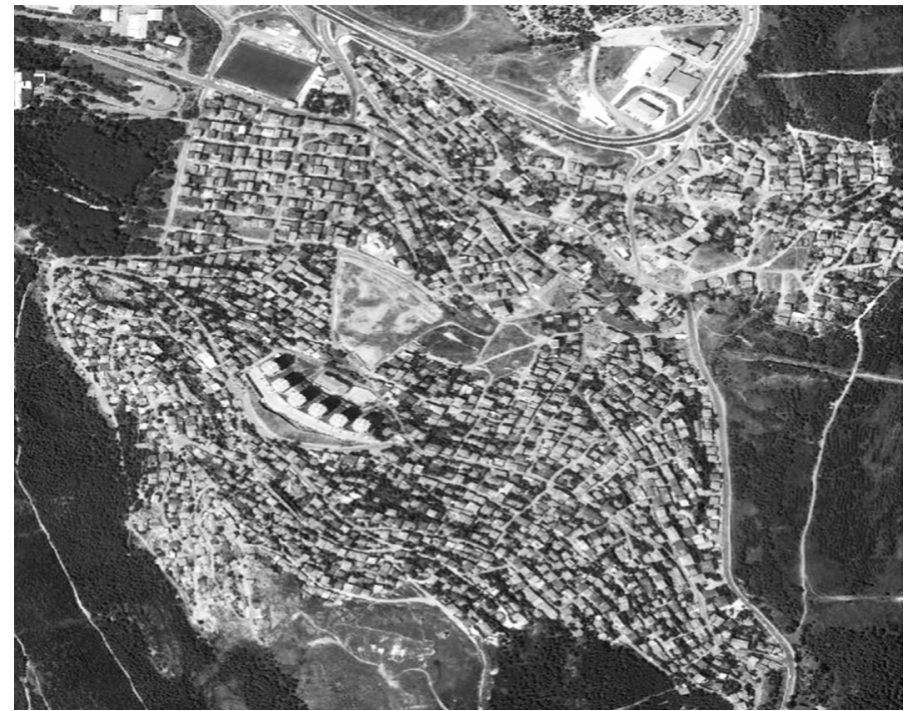

Fig. 1. Maltepe / Başıbüyük Housing Settlement [8].

\section{A. Informal Housing Settlements}

Although not explicitly designed, planned and projected by architects, urban planners or policy makers in Turkey, public spaces have emerged in Istanbul's squatter settlements that often adapt to the needs of the squatter residents. These open space forms and uses are the result of the social structures widespread in the Turkish squatter neighbourhood. There are numerous definitions to describe the housing of the urban poor, but there is little agreement over definitions. Informal and illegal is used in the research interchangeably. Another definition is "self-help" which is frequently synonymous with these terms. "Squatter" is used when the building is constructed without permission, in other words in illegal way.

The order in a squatter settlement lies in the mind and not in the physical environment itself, also not in the social structuring of the physical environment. For example, initially the square cell is placed on the surface, and then further squares of the similar sizes are randomly aggregated by joining one full side of each onto a side already in the system, preserving the existing other side.

This case identifies the modes of transformation of architectural and urban space. "Space" in this study was conceptualized as a social, economic and political form that materializes, crystallizes and accumulates in it. This paper identifies the modes of transformation of organic illegal housing structures by explaining the legal structures of Housing Development Administration (TOKI) and the social and spatial patterns. In order to develop an
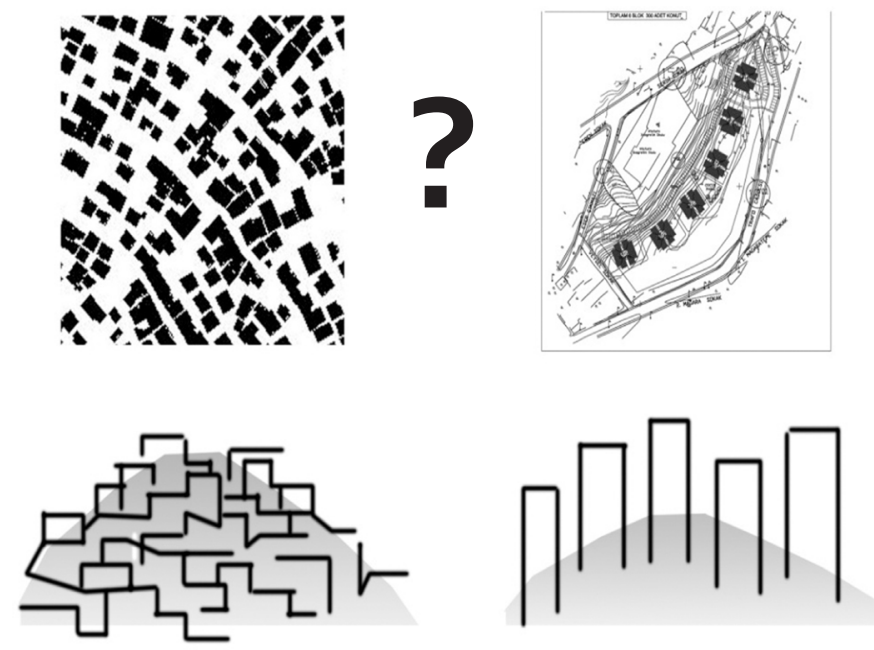

Fig. 2. The diagram of informal and formal housing patterns [a diagram by the author].

argument for the spatial specificity against segregation this paper uses the notion of social-spatial consideration as its main tool.

\section{B. Parameters}

There are lots of housing design parameters such as physical, social and economic parameters that must be taken into consideration in urban transformation. Forms of informal housing are good examples to see how physical parameters are used in spatial organization of the units. Arrangement of cells, entrance of housing units, respect to other space, continuous structure of open space, public space relation, substantial variation in building geometry and room arrangement will be considered as physical parameters within the context of this paper. In addition to the physical parameters, dynamic social relation that is a fundamental aspect of spatial form will also be introduced as another parameter.

\section{CASE Study: Maltepe/ Istanbul}

Maltepe/ Başıüyük in Istanbul is selected as the case study for analyzing the formal housing and the informal housing settlement. Başıüyük is one of the squatter settlements in Maltepe district on the Anatolian side of Istanbul. This old settlement is located at the North end of the E-5 highway, on the slope of the hill overlooking the Marmara Sea. According to 2012 data population of Başıbüyük is 20528 [5].

The major discussion and the argument in this study are 


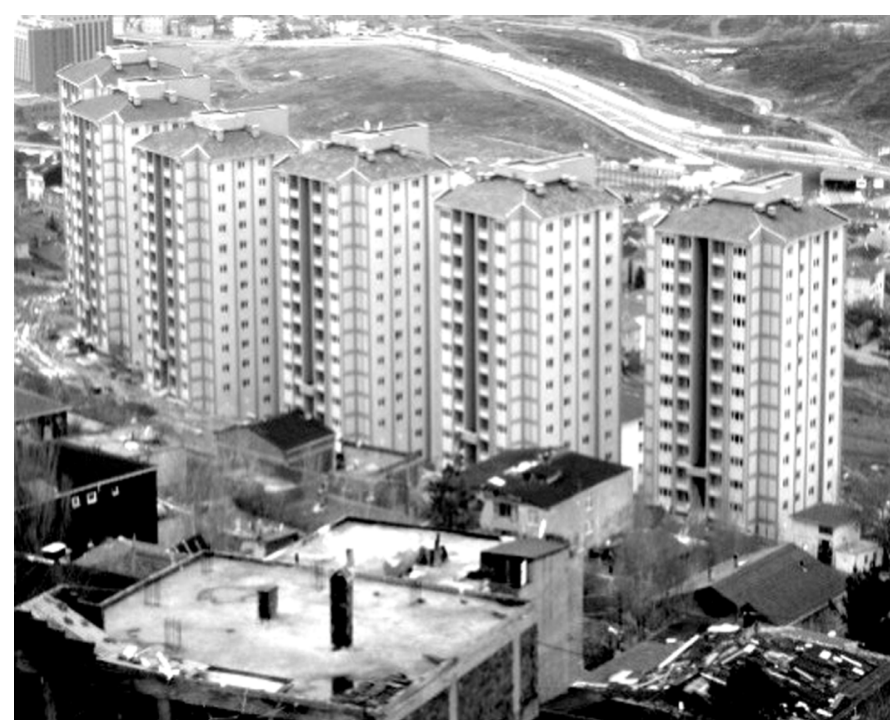

Fig. 3. Maltepe/ Başıbüyük TOKİ Blocks (Photo: Maltepe Municipality).

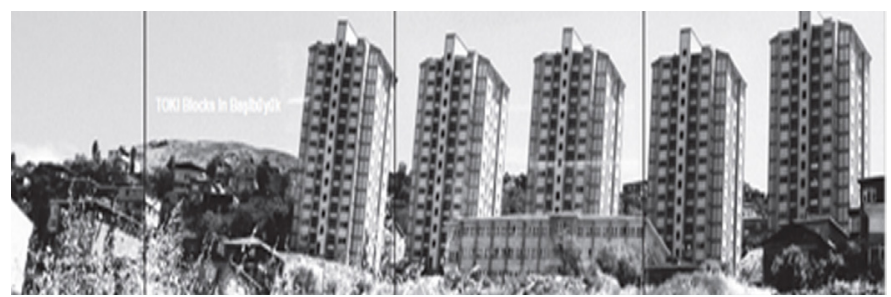

Fig. 4. Maltepe / Başı̈̈̈yük TOKİ Blocks [7].

derived from ongoing fieldwork. The first step is the housing projects and the processes of urbanization in Istanbul in general. The second step is the social housing project of TOKI (Housing Development Administration) that has been constructed instead of organic and incremental squatter pattern.

Başıüyük demonstrates a general perspective to show the polar differences that are seen in the city of Istanbul. Looking from the top of the hill new high rises and the rapidly disappearing settlements of the previous generation can be seen. Six towers (Fig. 3), (Fig. 4) are standing on the side of the hill surrounded by informal housing pattern built by squatters [6].

In order to develop an argument for the spatial specificity against segregation, this paper used the notion of social-spatial consideration as its main tool. Observation, actual sources and parametric evaluation was used to reconstruct its space-time contexts.

\section{PARAMETRIC EVALUATION}

As a result of observation and field research made in Maltepe/ Başıüyük informal housing settlement; physical, environmental quality and social reinforcement design parameters were evaluated as insufficient. When TOKI social housing Project was evaluated it was observed that the formal housing blocks have been designed detached from the ground and do not meet other parameters, except social facility spaces. When examined

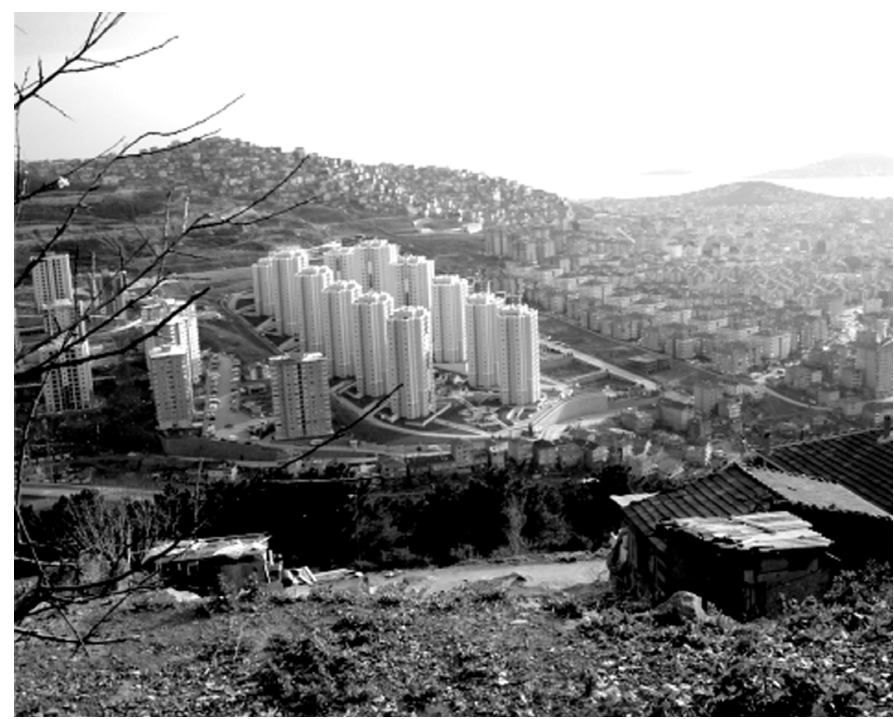

Fig. 5. Formal Housing Settlement: KİPTAŞ (Istanbul Residence Development Plan Industry and Trade Inc.) [8].

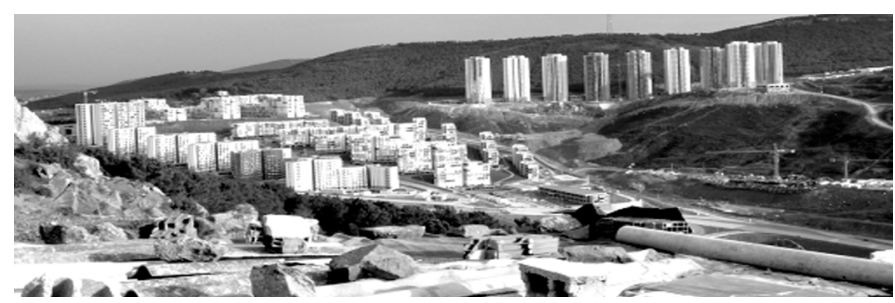

Fig. 6. Formal Housing Settlements: Narcity and KIPTAȘ (Istanbul Residence Development Plan Industry and Trade Inc.) [8].

on the settlement scale, the current public space has not been used effectively; there is a disconnection between the public space and housing settlements. Environmental adaptability and design (Table III) seems insufficient in terms of diversity. Also, standard types of projects to reduce the cost of housing and the use of standard materials due to the diversity in design is minimized. The presence of local building materials that can be seen in informal housing pattern is not seen in the formal housing pattern.

Parameters related to the settlement (Table III) were determined as follows: compliance with microclimate and land, topography, distance between buildings, housing-public space relation, harmony with the nature, quality of physical environment, social spaces, environmental harmony, use of local data in design.

Looking at the scale of architectural design in the informal residential structure, the built environment is oriented in the south-west direction. Local materials such as brick, metal, wood and recycled materials are used. According to different user profiles, functional and spatial solutions to provide user satisfaction are available. In terms of spatial and social sustainability informal settlements provide most of the parameters (Table II).

The informal housing settlement is positioned on the hillside and does not interrupt the view of each other, the sun and the wind. In micro-scale the housing settlement is open to spatial development. By the participation of new individuals of the family to the residence, housing is capa- 
TABLE II

INFORMAL / FORMAL HOUSING DESIGN PARAMETERS

\begin{tabular}{|c|c|c|c|}
\hline \multicolumn{2}{|c|}{$\begin{array}{l}\text { HOUSING DESIGN PARAM- } \\
\text { ETERS } \\
\text { *PG: Parameter Group } \\
\text { PG1: Settlement } \\
\text { PG2: Architectural Design } \\
\text { PG3: Infrastructure }\end{array}$} & $\begin{array}{l}\text { INFORMAL/ } \\
\text { SQUATTER PAT- } \\
\text { TERN } \\
\text { Maltepe/ } \\
\text { Bassibüyük }\end{array}$ & $\begin{array}{l}\text { FORMAL/ } \\
\text { TOKİ } \\
\text { Maltepe/ } \\
\text { Başıüyük }\end{array}$ \\
\hline \multirow[t]{5}{*}{ PG1 } & $\begin{array}{l}\text { Housing-public space } \\
\text { relation }\end{array}$ & 1 & 0 \\
\hline & $\begin{array}{l}\text { Physical environment } \\
\text { quality }\end{array}$ & 0 & 0 \\
\hline & Social areas & 1 & 1 \\
\hline & $\begin{array}{l}\text { Local data use in } \\
\text { design }\end{array}$ & 1 & 0 \\
\hline & SUBTOTAL & 3 & 1 \\
\hline \multirow[t]{11}{*}{ PG2 } & Diversity in design & 1 & 0 \\
\hline & Material variety & 1 & 0 \\
\hline & $\begin{array}{l}\text { Technological con- } \\
\text { struction facility }\end{array}$ & 0 & 1 \\
\hline & Functionality & 1 & 0 \\
\hline & $\begin{array}{l}\text { The ability of } \\
\text { open-endedness in } \\
\text { design }\end{array}$ & 1 & 0 \\
\hline & Different user profiles & 1 & 0 \\
\hline & Aesthetic harmony & 1 & 0 \\
\hline & User Satisfaction & 1 & 0 \\
\hline & Spatial sustainability & 1 & 0 \\
\hline & Social sustainability & 1 & 0 \\
\hline & SUBTOTAL & 9 & 1 \\
\hline \multirow[t]{5}{*}{ PG3 } & Transportation & 0 & 0 \\
\hline & Sewage & 0 & 1 \\
\hline & Service access & 0 & 0 \\
\hline & SUBTOTAL & 0 & 1 \\
\hline & TOTAL & 12 & 3 \\
\hline
\end{tabular}

ble of spatial flexibility by changing and transforming.

When the architectural design parameters (Table II) of the public social housing (TOKI) were analysed there has been no analysis in terms of orientation in the design process. In the standard type of social housing project proposals, which are developed through site plan, typical and economical materials are used. Since user profile is ignored in the design process, the standard housing types couldn't satisfy the user needs. In terms of aesthetic harmony parameters TOKI housing project could not be in harmony with the urban environment, in terms of spatial and social sustainability the parameters are negative.

In addition to the infrastructural parameters that are not provided in the formation of informal housing settlements, transportation, sewage and access to services were also observed as
TABLE III

INFORMAL / FORMAL HOUSING DESIGN PARAMETERS

\begin{tabular}{|l|l|l|}
\hline INFORMAL / FORMAL HOUS- & INFORMAL/ & FORMAL/ \\
ING DESIGN PARAMETERS & SQUATTER PAT- & TOKI \\
*PG: Parameter Group & TERN & Maltepe/ \\
Başıüyük & \\
PG1: Settlement & Başı̈口yük & \\
PG2: Architectural Design &
\end{tabular}

\begin{tabular}{|c|c|c|c|}
\hline \multirow[t]{14}{*}{ PG1 } & \multicolumn{3}{|c|}{ Evaluation of Natural Environment } \\
\hline & $\begin{array}{l}\text { Adaptation to the } \\
\text { natural environment }\end{array}$ & 1 & 0 \\
\hline & $\begin{array}{l}\text { Adaptation to the } \\
\text { microclimate }\end{array}$ & 1 & 0 \\
\hline & $\begin{array}{l}\text { Adaptation to the } \\
\text { topography }\end{array}$ & 1 & 0 \\
\hline & \multicolumn{3}{|c|}{ Evaluation of Artificial Environment } \\
\hline & Orientation of units & 1 & 0 \\
\hline & $\begin{array}{l}\text { Distance between } \\
\text { housing units }\end{array}$ & 1 & 0 \\
\hline & Building configuration & 1 & 0 \\
\hline & Settlement density & 1 & 1 \\
\hline & $\begin{array}{l}\text { Design depending on } \\
\text { the place }\end{array}$ & 1 & 0 \\
\hline & Cultural diversity & 1 & 0 \\
\hline & $\begin{array}{l}\text { Use of local data in } \\
\text { design }\end{array}$ & 1 & 0 \\
\hline & Service Systems & 0 & 1 \\
\hline & Infrastructure & 0 & 1 \\
\hline \multirow[t]{3}{*}{ PG2 } & \multicolumn{3}{|c|}{ Evaluation of Natural Environment } \\
\hline & $\begin{array}{l}\text { Adequacy of the over- } \\
\text { all design concept }\end{array}$ & 1 & 1 \\
\hline & $\begin{array}{l}\text { Health / Safety } \\
\text { requirements }\end{array}$ & 0 & 1 \\
\hline
\end{tabular}

inadequate. On the other hand, in the Project of TOKI access to services for the transportation is inadequate, though the infrastructure has been designed in advance. Although there are economic constraints informal housing producers manufacture their own form of structures and materials, which they are free to choose for themselves without external pressure and control. This situation can reflect their individuality and their lifestyle, it is important to be unique and individual.

\section{CONCLUSION}

Informal settlements generally have been defined in negative terms in relation to the formal pattern of the city. There is inefficient use of parameters such as legality, infrastructure, and absence of socio-economic opportunities. In com- 
TABLE III (Cont.)

INFORMAL / FORMAL HOUSING DESIGN PARAMETERS

\begin{tabular}{|c|c|c|c|}
\hline \multirow[t]{31}{*}{ PG2 } & \multicolumn{3}{|c|}{ Evaluation of Artificial Environment } \\
\hline & Easy access & 0 & 1 \\
\hline & Building Climate Adaptation & 1 & 1 \\
\hline & Building Shell Design & 1 & 1 \\
\hline & Health / Safety requirements & 0 & 1 \\
\hline & $\begin{array}{l}\text { Heating / Cooling Systems } \\
\text { Capability }\end{array}$ & 0 & 1 \\
\hline & $\begin{array}{l}\text { Plumbing / Electrical Com- } \\
\text { petence }\end{array}$ & 0 & 1 \\
\hline & $\begin{array}{l}\text { Adequacy of finishing } \\
\text { materials }\end{array}$ & 0 & 1 \\
\hline & Lighting adequacy & 0 & 1 \\
\hline & Endurance ability & 0 & 1 \\
\hline & Technology use & 0 & 1 \\
\hline & Order & 0 & 1 \\
\hline & Interior attractiveness & 1 & 0 \\
\hline & Exterior attractiveness & 1 & 0 \\
\hline & Flexibility capability & 1 & 0 \\
\hline & Variability capability & 1 & 0 \\
\hline & Reversibility capability & 1 & 0 \\
\hline & Integration capability & 1 & 0 \\
\hline & Uncertainty in design & 1 & 0 \\
\hline & Continuity & 1 & 1 \\
\hline & Spatial relation ability & 1 & 0 \\
\hline & Circulation area adequacy & 1 & 0 \\
\hline & \multicolumn{3}{|c|}{ Evaluation of Social Environment } \\
\hline & Individualization level & 1 & 0 \\
\hline & Social activity adequacy & 1 & 0 \\
\hline & Local values & 1 & 0 \\
\hline & Cultural diversity & 1 & 0 \\
\hline & \multicolumn{3}{|l|}{ Economical Evaluation } \\
\hline & Project cost & 0 & 1 \\
\hline & Construct. cost & 1 & 0 \\
\hline & Operational cost & 0 & 1 \\
\hline & TOTAL & 28 & 19 \\
\hline
\end{tabular}

parison with TOKI social housing blocks the informal settlements have the spatial richness and identity. However, such an interpretation could lead to new design approaches, considering not only destroying but also thinking of the parameters that could be transformed into new social housing forms.

Systematic design/parametric methods (Fig. 7) could be proposed to institutions. By evaluating all parameters in the design process more rational results can be obtained. Instead of the inductive design process the deductive design process could be used in formal housing applications.

Housing design requires interdisciplinary studies in urban and architectural scale. Institutions and experts have to come together to design formal social housing. In the design process parameter evaluation, systematic and paramet-

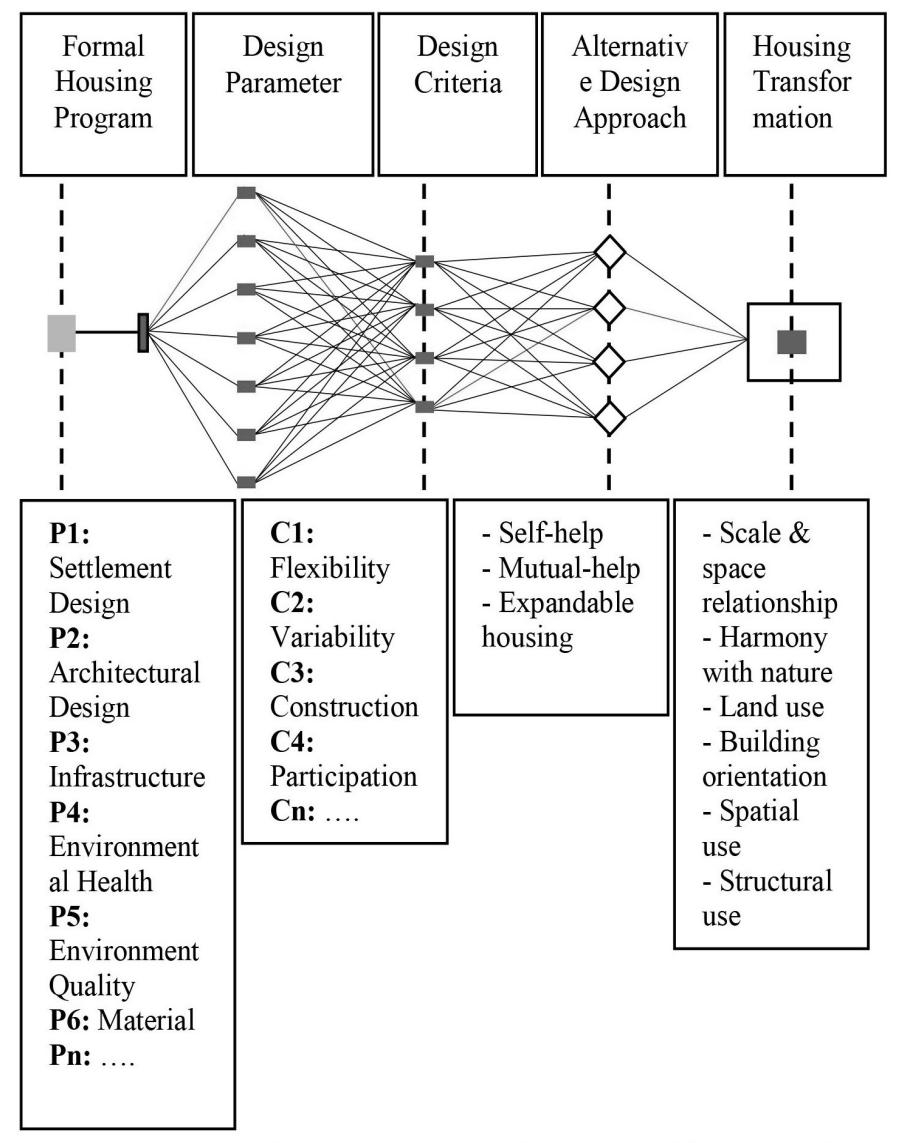

Fig. 7. Systemic design approach in formal housing design [source: Akçabozan, A., Demir, Y. Master Thesis: "A Comparative Evaluation of Design Parameters Affecting the Formation of Informal and Formal Housing Settlements"].

ric design approach for residential development is important.

Solutions for the informal housing problem should be presented. Rather than the ones in informal housing settlements, solutions provided for formal housing are more inadequate in terms of quality that does not provide the required design parameters.

In today's formal approach to social housing, it can be seen that several parameters have been overlooked in the design process. On the scale of settlement and architectural design many parameters, such as socio-cultural and economic parameters are ignored and not included in the design process.

Implementation of standard type housing projects everywhere is not a sustainable approach. Physical, social, cultural, economic, technological, etc. parameters must be used in the design and evaluation process.

Informal and formal housing design parameters and concepts could be investigated and in future, for the formal recommendations to be made in informal housing settlements issue, systematic parametric design method can be proposed. Alternative system approaches can be developed by using all of the parameters.

In the sustainable housing design and development process it is important to use resources efficiently, to reduce costs and to prevent from proliferation. To create and to direct bal- 
anced and controlled growing residential areas formal and spatial planning of housing at the level of settlement the necessary changes can be made in the housing design process.

As a result, in the transformation of informal housing into the formal housing, systemic design approach could be developed by analyzing and evaluating all design parameters which are effective in the formation of housing design. The parameter analysis and evaluation could give the direction to new design and planning approaches.

Housing design is not a heuristic process; it is a multi-dimensional and multi-disciplinary process. Therefore, by specialized designers taking part in the process and utilizing parametric design approaches positive results in architectural and urban scale can be achieved. Parametric evaluation and systemic design approach could be an effective methodology to develop new formal housing patterns.

\section{REFERENCES}

1. Derviş, P., Tanju B., Tanyeli U. [ed.]. Becoming Istanbul : An Encyclopedia. Istanbul: Garanti Gallery, 2008. 383 p. ISBN 978-9944-731-06-5

2. Davis, M. Planet of Slums. Istanbul: Metis, 2006. 256 p.

3. Kiray, M., B. Social Change and New Types of Dwellings in Turkey. Design Methods and Theories, 13, no 3/4. Istanbul, 1979, pp. 153-155.

4. Evers, H.-D., Korff, R. Southeast Asia Urbanism : The Meaning and Power of Social Space. New York: St. Martin's Press, 2000. 269 p.

5. Population of Başıbüyük [online]. Turkish Statistical Institute, 2012. [cited 10.12.2013]. http://www.tuik.gov.tr/

6. Short, P. Housing in Istanbul : 100 Percent User Satisfaction? [online]. Pulitzer Center, 2014 [cited 05.09.2014]. http://pulitzercenter.org/reporting/ eurasia-turkey-istanbul-developed-construction-housing-gecekondu-toki.

7. Johnson, C., Adanal, Y. Forced Evictions in Istanbul Living in Voluntary and Involuntary Exclusion, p.13 [cited 10.12.2013]. http://reclaimistanbul. files.wordpress.com/2011/04/diwan istanbul living in exclusion.pdf

8. Archive of Maltepe Municipality Planning Department. Maltepe Başıbüyük Urban Transformation Project : 2012 documents [CD-ROM].

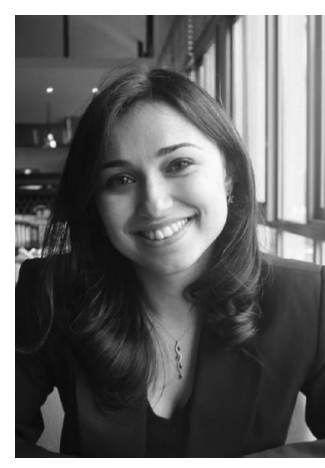

Aylin Akçabozan received the B.E. degree in architecture from the Istanbul Technical University, Istanbul, in 2011, and the Ms. Science degree in architectural design from the Istanbul Technical University, Istanbul, Turkey, in 2013. She is continuing her studies for Ph.D. in Restoration Program in Ylldız Technical University, Istanbul, Turkey. In 2013, she joined the Department of Architecture, Y1ldiz Technical University, as a Research Assistant. She was an Architect in Maltepe Municipality, Project Design Department in 2011. Her current research interests are architectural design, urban design, restoration, new architecture in historic environment, world heritage. She is a member of Chamber of Architecture in Istanbul. She received the Great Honour Award in 2006 from Urban and Regional Department, Istanbul Technical University, Istanbul.

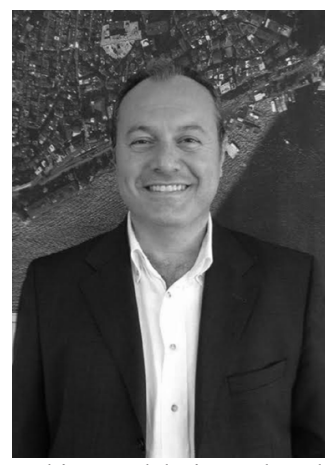

Yüksel Demir received the B.E. degree in architecture from the Istanbul Technical University, Istanbul, in 1987, and the Ms. Science and $\mathrm{Ph} . \mathrm{D}$. degrees in architectural design from the Istanbul Technical University, Istanbul, Turkey, in 1990 and 2001, respectively. In 1989, he joined the Department of Architecture, Istanbul Technical University, as a Lecturer, and in 2002 became an Assistant Professor. Since December 2012, he has been with the Department of Architecture, I.T.U, where he was an Assistant Professor and became an Associate Professor in 2012. His current research interests are architectural design, urban design and computer aided design, computer applications, information systems, visual communication. Dr. Demir is Head of I.T.U. Fine Arts Department, Istanbul; the director and founder of MARDINT: ITU Mardin Interdisciplinary Education Research \& Development Center. He has been a Board Member of the I.T.U. Faculty of Architecture. He was the recipient of the Acquisition Price "Küçükçekmece Town Centre Urban Design Competition in 2008; "i̇TÜ Taşkışla - Gümüşsuyu Campus Architecture \& Urban Design Competition Prizee; "Senior Residence International Project Competition", 1st Prizee in 2004; “İ.T.Ü. House Competition”, (with S. Velioğlu), 2nd Prizee in 2001.

\section{CONTACT DATA}

Aylin Akcabozan

Department of Architecture, Yıldız Technical University

Address: Barbaros, Beşiktaş, Istanbul, Turkey, 34349.

Phone: +905054970414

E-mail: aylin.akcabozan@gmail.com

\section{Yüksel Demir}

Department of Architecture, Istanbul Technical University

Address: Taşkışla, Beyoğlu, Istanbul, Turkey, 34743.

Phone: +905322476767

E-mail: yukseldemir@gmail.com 